\title{
Men and Place: Male Identity and the Meaning of Place in the Nineteenth-Century Scottish Gàidhealtachd
}

\author{
Elizabeth Ritchie
}

Centre of History, University of the Highlands and Islands, Dornoch IV25 3HN, UK; elizabeth.ritchie@uhi.ac.uk

Received: 28 March 2020; Accepted: 27 August 2020; Published: 26 September 2020

\begin{abstract}
The perfunctory noting of name, dates, family relationships and a location on gravestones initially suggests that such details are unprofitable sources for evidence of male identity. However the sheer commonplaceness of stating a placename, particularly when it is noticeably associated with men rather than women, and when not all cultures do the same, indicates that it may reveal something of how men thought of themselves and how they felt. Canadian and Australian studies have suggested that recording placenames on a headstone was a marker of Scottish ethnicity, like an image of a thistle. However, in the nineteenth-century Scottish Highlands ethnicity was not a key component of identity. Indications of place, at least in the 'home' country, must therefore signify a different element of identity. This article examines headstone inscriptions of men from across the Gaelic-speaking Highlands and Islands of Scotland who died in the nineteenth century. The resulting evidence indicates that place was a significant element of male identity, indicating personal or ancestral connection with a particular location; a regional affiliation; professional success; social status; national and international mobility; an imperial or patriotic mindset; or even geographical dislocation. In short, place was highly significant to nineteenth-century Highland men, and was a key element of their personal identity.
\end{abstract}

Keywords: masculinity; identity; Scotland; Highlands; gravestone; gender

\section{Introduction}

Late in November 1860, seventy-eight-year-old John Lamont breathed his last. He was a farmer in Kirkapol, on the Scottish island of Tiree, in the southern Hebrides. After his burial his children erected a headstone. It noted their father's name, age, year of birth, occupation, his emotional attachment to themselves and his friends. It also ensured that Lamont was clearly associated with two specific places: Ruaig, where he was born, and Kirkapol where he had farmed and where he had died. ${ }^{1}$ Noting places alongside names, particularly men's names, is almost ubiquitous on nineteenth-century Scottish gravestones. This article demonstrates that an intrinsic part of male identity in the Scottish Gàidhealtachd (Gaelic-speaking area) was formed through men's relationship to place. This attribute can be seen through gravestone evidence in three ways. First is by the arrangement of some graveyards to keep members of specific geographical (and probably also kin) communities together. More commonly, inscriptions clearly identify individuals with specific places through multigenerational connections; dislocation from those places by eviction or clearance; or through professional association. Lastly, far from reflecting a gemeinschaft, many headstones evidence masculine mobility, with places used to

1 The full inscription reads: 'Sacred to the memory of John Lamont, farmer Kirkapol, Tyree who was born at Ruaig in the year 1782 and died at Kirkapol on the 30 November 1860 at the age 78 years deeply regretted by a wide circle of friends and acquaintances erected by his affectionate children'. http://www.tireegraves.org.uk/ (Tiree Gravestones n.d.) (accessed on 24 September 2019). 
trace life stories through space and time, creating regional, national or imperial identities. The latter two categories are usually closely bound up with claims of social status. Place was highly significant to nineteenth-century Highland men, and was a key element of their personal identity.

\section{Literature Review}

Gravestones have been identified as fertile fields of evidence for expressions of identity. ${ }^{2}$ In England, Susan Buckham has pointed out that memorials are used to display class, status and family relationships (Buckham 2003, p. 161). However an unrecognised theme is gender. Joy Giguere found that headstones in Maine in the United States indicated social status in highly gendered ways: men's through displaying titles and occupations; and women's by connecting them to family members and domestic virtues (Giguere 2007, p. 1). Giguere argues that these idealised commemorations act to 'encourage the living to follow gendered codes of moral and social behaviour according to age, sex and marital status', functioning as 'a form of psychologically driven social control' (Giguere 2007, p. 1). There are strong similarities between the English and Maine inscriptions and those in the Scottish Highlands and Islands, and presumably they functioned in similar ways by promoting family status and a set of social mores, as well as expressing personal identities. ${ }^{3}$

One element, however, which either does not appear on the stones studied by Buckham or Giguere, or which they have disregarded, is placenames. John Lamont's unpretentious inscription is entirely typical in privileging place along with name, dates, family relations and occupation, so surely this ought to be given equal consideration. Place as part of men's personal identity does not fit easily into current academic definitions of masculinity. Lynn Abrams and Elizabeth Ewan introduced their seminal collection of essays by defining this concept as a 'set of practices and roles, expectations and attributes, which shape the ways in which men act ... and the ways in which their actions are represented and understood' (Abrams and Ewan 2017, p. 2). An identity partly based on place is not a practice, nor an attribute, unlike other elements of gravestone inscriptions. Scholars of identity, such as those developing the history of masculinity in Scotland, understand gender identities to be 'plural, multifaceted and complex' (Abrams and Ewan 2017, p. 2). The ubiquity of placenames on Scottish grave markers, particularly those of men, surely indicates that place was also a vital aspect of how men were conceived of and how they constructed themselves.

Most studies which have considered place and identity through burial practices have focused on immigrant communities. While Frances Swyripa found that Mennonite and Ukrainian immigrants to Canada rarely recorded place of origin on their gravestones, the Scots did, as found by Leigh Straw in Tasmania and by Laurie Stanley-Blackwell and Michael Linkletter in Nova Scotia (Straw cited in Wilkie 2015, p. 159; Stanley-Blackwell and Linkletter 2018, p. 4). At first glance, this citing of placenames appears to sentimentally tie migrant Scots to their ancestral birthplace while expressing an ethnically specific identity. Indeed Eva Reimers notes that 'symbols ... have to deviate from the norm, thereby creating a boundary against the majority, in order to serve as markers and expressions of ethnic or cultural identity' (Reimers 1999, p. 153). Ethnically distinctive features have therefore, understandably, been interpreted as conscious expressions of ethnic identity. This may indeed be the case when symbols, such as the Scottish thistle, are widely adopted by one group but not by others and when the feature does not particularly appear in the home country (Stanley-Blackwell and Linkletter 2020, p. 87). Other distinctive features among immigrant groups are not, however, self-consciously ethnic innovations, but simply continuations of the cultural practices of the homeland. Regarding Ukrainian architecture in western Canada, John Lehr explains that 'immigrants recreated a domestic landscape patterned on that of their homeland because it did not occur to them to do

2 Placename spellings are highly variable so when they are quoted I have used the spelling on the headstone rather than modern usage or the correct Gaelic. In the text I have used the current conventional spelling.

3 Similarly, Eva Reimers shows that before regulations over size, the forms and sizes of gravestones marked social and economic status (Reimers 1999, p. 154). 
otherwise' (Lehr 1989, p. 4). Building as deliberate ethnic expression came later, as symbolism of difference against the norm. These cultural habits therefore reflect other aspects of identity than ethnicity: perhaps gender, linguistic or class identities. Among Scots, one of these is place. See Figure 1.

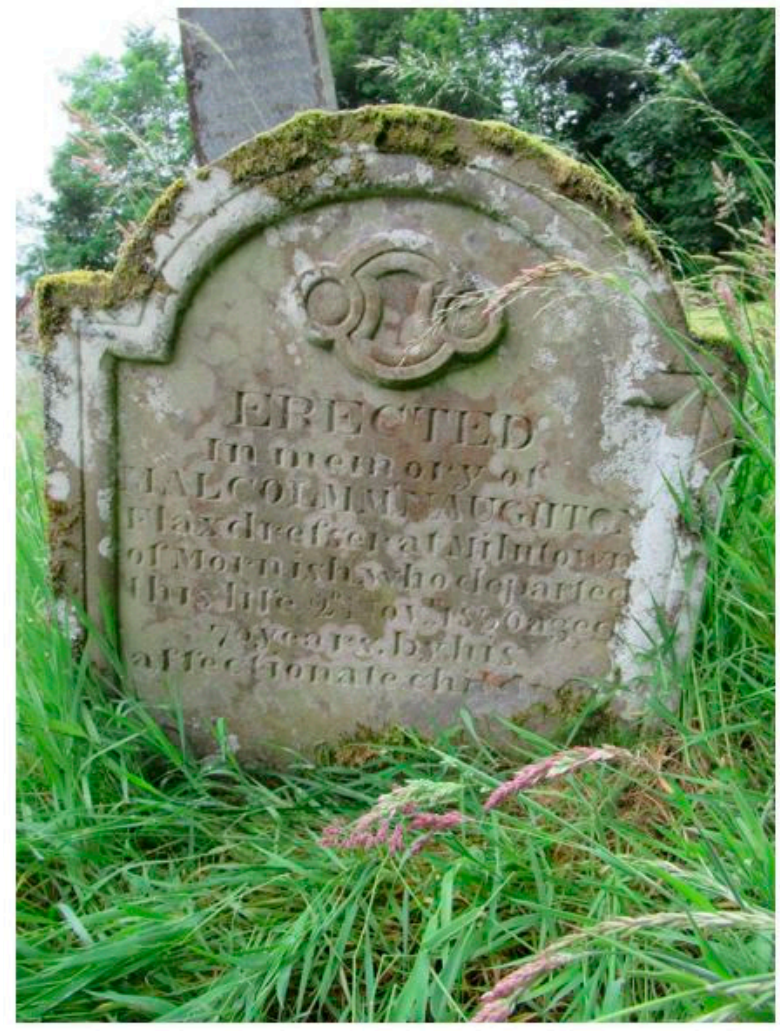

Figure 1. A typical memorial: it notes Malcolm McNaughton's name, his occupation (flaxdresser), where he is from (Milntown of Mornish—which is near Killin in Perthshire), his dates and who erected the stone. All photos are by the author.

Yi-Fu Tuan coined the term 'topophilia' to explain that attachment to place goes beyond geographical knowledge. Rather it encompasses 'feelings, dreams, hopes, values and beliefs' (Tuan 1974; cited in MacDonald 2017, p. 159). Michael Newton has proposed that the Gaelic notion of landscape is 'a touchstone of identity ... reinforce[ing] the connection between people and place' (Newton 2009, p. 296). What was the meaning, the nature, of this connection expressed on so many stones? Reimers comments that occasionally Swedish gravestones note place of birth. Unlike in Scotland, this custom is usually to convey that a person was born in a place other than where they are buried. Swedish identity is assumed so gravestone inscriptions only note a deviation from that norm (Reimers 1999, p. 153). Scots buried in Scotland had no need to assert ethnic identity, no need to crystallise a new community and, unlike among the colonists in Nova Scotia, place and time were not divided into before and after immigration. While a colonial context may well have invested the practice with new meaning, in the home country the noting of place clearly has a different purpose.

\section{Materials and Methods}

In this article, I have focused on male identities in the Gaelic-speaking Highlands and Islands of Scotland for three reasons. Many researchers who have utilised inscriptions to interrogate identity have focused on ethnicity, so examining a region where the creation or expression of ethnicity was not a concern permits us to see other identities which were felt and projected. Secondly, while scholars have recently developed a corpus of work on Scottish masculinities, best summarised in Abrams and 
Ewan's edited collection, most of the focus has so far been on urban or Lowland Scotland. ${ }^{4}$ Lastly, Gaelic speakers have left fewer documentary clues for historians than have English speakers. Although most headstones are in English, they are, nonetheless, the voices of Gaels and this evidence should be acknowledged. This survey therefore uses inscriptions found in graveyards north and west of a line from Argyll, through Perthshire and Badenoch to the Moray Firth excepting the Northern Isles. ${ }^{5}$ I include men who died in the nineteenth century, and a few in the very early twentieth. This approach is partly to capture those who died at a time when substantial numbers of inscribed stones were created and partly because it was an economically, socially and culturally distinctive period: crofting society was being established and consolidated in the region as part of the commercialisation of the British economy, while the British Empire was reaching its apex.

I was able to access inscriptions online for Tiree and Skye, but I sourced the rest by travelling to sixty graveyards, photographing stones and transcribing key information into a database to enable keyword and thematic analysis. ${ }^{6}$ It is not possible to accurately state the proportions of stones I used versus those present, as most were in ancient graveyards where many were illegible, moss-covered or even evidenced only by a hard, rectangular mound in the ground. See Figure 2a,b. I therefore captured representative samples in each graveyard, seeking out class and regional variations. The vast majority of my inscriptions were for Protestants, although two graveyards (in Ballachulish and Blair Atholl) were around Episcopalian churches and one (Morar) was Roman Catholic. There was no noticeable variation although, considering the significant differences found by Stanley-Blackwell and Linkletter in Nova Scotia, further research might be profitable (Stanley-Blackwell and Linkletter 2020, pp. 87-88). I found that inscriptions about men could largely be separated into four expressions of identity: religious; occupational; relational (whether by blood, marriage or friendship); and geographical. The latter is usually expressed in basic and stark terms and is commonplace. That placenames are, however, most frequently recorded for men and that it is not a pan-European practice strongly suggests that this is a culturally specific phenomenon which relates to male identity.

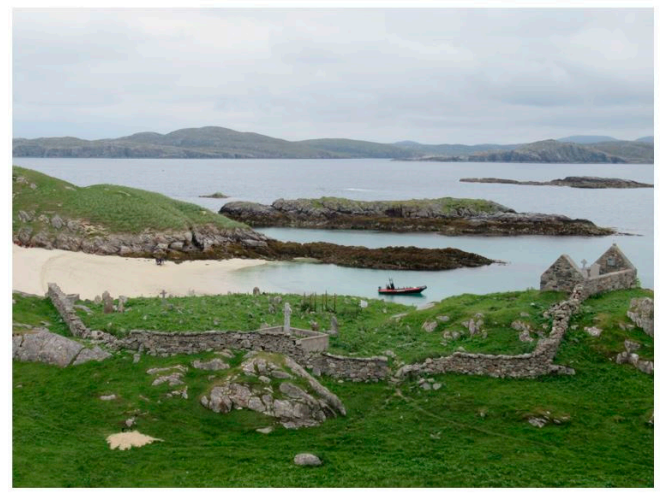

(a)

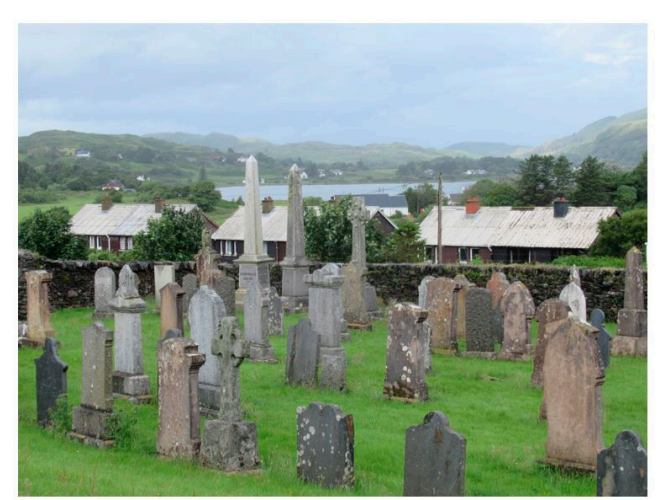

(b)

Figure 2. (a,b) The ancient burial ground on Little Bernera, a small Outer Hebridean island, shows characteristic irregularity and a preponderance of small, anonymous stone markers. This arrangement is in contrast to the more regular rows of the more modern graveyard at Balvicar in Argyll. The latter graveyard also features many headstones made from local slate which retain legible inscriptions.

4 I do not claim that these results are unique to men in North West Scotland. A comparison with urban and Lowland areas is required.

5 I surveyed a few graveyards in the predominantly English-/Scots-speaking county of Caithness, though mainly on the border with Sutherland where there was considerable linguistic overlap. Similarly the parish of Edinkillie sits in Moray but on the edge of the Gaelic-speaking region of Strathspey to the south.

6 While there is a publication by Cowper and Ross (1989), entitled Sutherland Monumental Inscriptions pre 1855, as I live in the county I chose to visit an extensive selection of graveyards in order to get a sense of the material culture of the headstones and the layout of the graveyards. Additionally, I wanted to study inscriptions from the later nineteenth century. There are comparable volumes on monumental inscriptions in various other counties. 
There has been no shortage of work done on graveyards and gravestones in Scotland. Almost all has been documentary. A.S. Cowper and I. Ross have compiled thousands of inscriptions, as have various heritage societies for their own localities. Some have been made available online. Others have studied the symbolism and material culture of graveyards and headstones, producing useful reference works for interpreting these places and objects. With the possible exception of Dane Love's (1989) analytical survey there is not, however, a literature utilising these objects and texts as historical sources and endeavouring thereby to draw conclusions about the culture, mindset, or experience of people in the past. This gap is possibly due to a too-rigid separation between the disciplines of genealogy and academic history and the inexperience of many Scottish academic historians in utilising material culture.

Gravestone inscriptions are highly problematic evidence, not least because the vast majority were not created by the deceased, but by their spouses, children or even much later descendants. This is often openly acknowledged, as can be seen in a number of the photographs featured. The inscriptions therefore indicate how those people wished the deceased to be remembered, knowing that both the inscription and the stone itself reflect on them. However, this simply means we cannot naively read inscriptions as accurate descriptions of individuals. Lehr has argued that graveyards commemorate not 'individuals but the society of which they were a part', while Stanley-Blackwell and Linkletter point out that stone and inscription embody 'both individual and collective identities' (Lehr 1989, p. 8; Stanley-Blackwell and Linkletter 2018, p. 8). Most documentary sources used by historians of masculinity tend to identify deviant or new behaviours or models (Abrams and Ewan 2017, p. 3). This is not the case, however, for gravestone inscriptions which are almost universally conservative and uncontroversial. Therefore, these documents give an insight into gendered identities which are commonly acclaimed and acceptable. So regardless of accuracy, what inscriptions indicate are socially acceptable traits which will resonate with the viewer, thereby honouring the dead man or his relations. They are therefore excellent evidence for discerning commonly recognised elements of male identity.

\section{Discussion of Findings I: Community Identity}

In some Highland graveyards burials appear to be organised by village or crofting township. This practice suggests that individuals' identities were partly constructed in terms of the geographical community they were from. There are many different types of communities. Elsewhere, I have discussed the Evangelical community which connected people of deep religious faith with each other across the Highlands through personal relationships built up by, for example, attending communions (Ritchie 2010, pp. 203-9). Ex-military men seem also to have felt a sense of community. However, gravestone evidence suggests that people drew a strong sense of identity from geographical communities-groups of people, often interrelated, who lived and worked together in a specific place. By the nineteenth century, clanship as a functioning system was long gone, but there is considerable evidence that people had strongly localised identities, associated with kin and with place. Abrams cites a number of assault cases demonstrating this, such as an incident at a wedding in 1828 when a fight broke out between the MacGillivrays from Arisaig and the MacPhails and MacDonalds from neighbouring Morar (Abrams 2013, pp. 108-9). On the west coast of Lewis, when the old graveyard at Cladh Mhuire was extended, the new site was arranged geographically. Each village, such as Lower Shader or Upper Shader, was allocated two rows, marked by a concrete post. This arrangement is uncommon in new graveyards which tend to be laid out chronologically, each new burial taking the plot beside the previous one. In older graveyards this communal identity is more normal, although often not obvious. In Kincardine, Sutherland, close inspection reveals that some nineteenth-century stones appear to be clustered by villages: in the south-east corner, for example, are the people from Invershin, and near them those from Gledfield. Further back are two small clusters (three or four stones) from Greenyards or Gruinards. These families are all named Ross or Munro, very common names in this area, which may or may not indicate these are extended family groups. In many English graveyards the spatial organisation 'mimicked the social inequalities between the living' (Buckham 2003, p. 163). 
Not only could the better-off afford elaborate headstones, but they could afford the more prestigious areas of the cemetery. This hierarchy is less apparent in Highland graveyards where spatial organisation sometimes reflected a kin or place-based corporate identity. This configuration included all members of families, however, it is men's inscriptions that particularly identify them with places specific to them as individuals.

\section{Discussion of Findings II: Individuals in Their Geographical and Social Places}

The sparse noting of places encodes many stories of how men identified themselves. These are, however, decipherable only through intimate knowledge of local history, genealogy and geography. Most men who associated with a place identified with one specific settlement, farm or estate. This was often noted alongside their occupation, for example 'Neil McLauchlan, late innkeeper, Dalwhinnie' (1774-1826); 'Thomas Calder, lockkeeper, Gairlochy' (1797-1870). These gravestones make the nature of the relationship between the man and a particular place explicit. This reference goes beyond mentioning where he lived, rather speaking to the depth of his knowledge of a place, and his association with that place in the minds of the rest of the community. Robert Cumming (1784-1854) was 'for many years merchant and postmaster at Lynwilg'; 'Angus Robertson, cattle dealer, Balenluig' (1801-1835); and John MacPherson (1845-1898) was 'shepherd at Loch Ericht-end'. Connections with place are frequently noted for men from multiple ranks of society, both those who lived under the old as well as the new commercial system: farmers, tacksmen, tenants, crofters, incoming professionals and ministers. What is also notable in the examples is that geographical place is usually linked with an indication of status-a man's social place.

Some men had a multigenerational connection with a particular piece of land. Invariably, when a man was noted as a farmer the inscription included the name of his farm. See Figure $3 a, b$. In many cases he would have been brought up there, inheriting ownership or, more likely, the tenancy from his father and passing it on to his son after working it all his life. John Ross (1777-1867) was 'late farmer, Achnahanat, Parish of Kincardine' and Alexander Anderson (1809-1871) was 'farmer, Nonikiln'. Such men may well have been known locally by the name of their farm rather than their family name. This was a convenient way to give by-names to distinguish men with common names, but it also spoke to an attitude about the nature of the relationship between place and people. Individual men, and even families who worked the land, existed only for decades, whereas the farms endured.

Tacksmen were more complicated. The tacksman was an important role within the hierarchical clanship system which was dominant into the eighteenth century. He was connected by kinship or friendship to the chief or landlord who granted him extensive lands to manage in return for rent in money and produce, and the requirement to raise fighting men when necessary. A principal tacksman then occasionally granted land under similar requirements to sub-tacksmen or, more generally, to sub-tenants of one or more townships. He was also actively involved in land management and land-based commercial enterprises, such as black cattle trading. This was probably the role fulfilled by men whose active life was in the eighteenth century, such as Donald MacMillan (1749-1807) 'late tacksman' of Callich, Kilmallie, or Samuel Lindsay (d. after 1800), tacksman of Glenogle. However, that men described themselves as tacksmen well into the nineteenth century, many decades after the demise of clanship, suggests the term expressed an element of male identity that went beyond simple description of social rank. ${ }^{8}$

7 This was a practice transferred to the colonies. Benjamin Wilkie notes that Donald Cameron from Inverness who settled in the Western District of New South Wales was distinguished from the many other Camerons by the name of his property 'Morgiana'. (Wilkie 2017, p. 87). There is a similarity here with Cape Breton miners, most of whom hailed from rural communities and were often given a nickname referring to their place of origin (Davey and MacKinnon 2001, p. 73).

8 This is not to say, as with all aspects of masculine identity, that this type of relationship to land must apply exclusively to men. David Taylor has found evidence of female 'tacksmen' and even a 'tackswoman'. (Taylor 2016, p. 26). That women ran tacks does not negate the evidence that being a tacksman was an important part of these men's gender identity. 


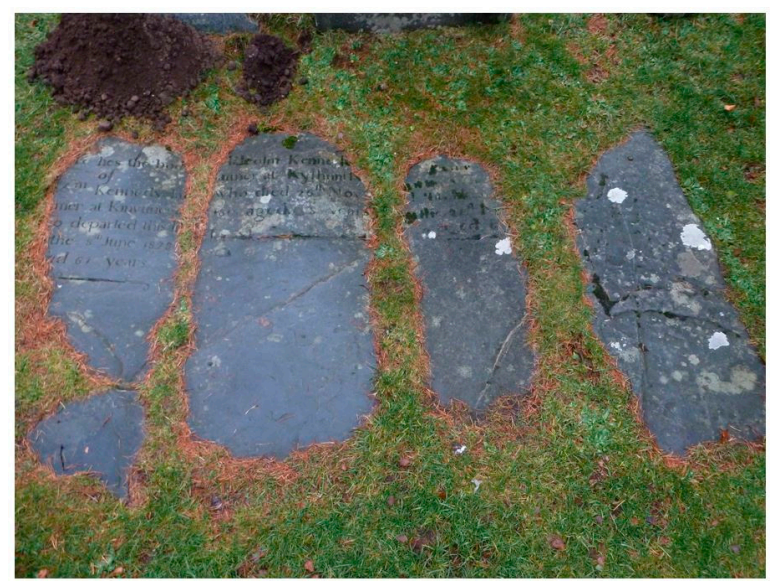

(a)

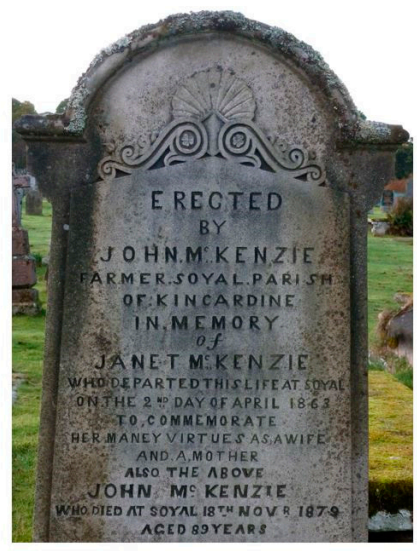

(b)

Figure 3. $(\mathbf{a}, \mathbf{b})$ The stones commemorating the Kennedy family of farmers lie beside each other in Alvie, Badenoch. John McKenzie, who farmed at Soyal in Kincardine, Sutherland, raised a stone to honour his wife Janet's 'many virtues as a wife and a mother'. As Joy Giguere found in New England, the epitaph lauds her for her role in the home and the family (Giguere 2007, p. 1). It is the husband's name, status and connection with place, however, which dominate the stone.

The notion of dùthchas is helpful in considering a connection to place for tacksmen (and indeed tenants). Edward Dwelly defines this as a 'hereditary right' while Robert Dodgshon explained that occupiers held land not by legal authority but by 'force of custom' or, according to Allan MacInnes, 'customary right of occupancy ... for three generations (Dwelly 1971, p. 375; Dodgshon 1981, p. 110, 113; MacInnes 1996, p. 16). Even as tacksmen began to be squeezed out as clanship was replaced by commercial relations, David Taylor notes the continuing attachment of many tacksman families to their dùthchas, that is, the 'long-held ties to lands embodying the heritage and culture of both family and clan over many generations' (Taylor forthcoming, Chapter 1). Commercialisation of the landlord-tenant relationship and the introduction of 'improvement' attitudes towards land and productivity often resulted in competitive bidding. Tacksmen and tenants therefore frequently bid high against each other or against incoming sheepfarmers in order to maintain possession, sometimes at risk of ruin. Lewis MacPherson, tacksman of Dalraddie, Badenoch, felt it was 'somehow deeply rooted in the minds of Highlanders to hold [onto] ... any lands in the possession of there [sic] forefathers' and offered so much that he had to 'strugle [sic] hard ... to pay the augmented Rents' (National Records of Scotland, GD44/27/11/119, Macpherson to Todd, 1773 cited in (Taylor 2016, p. 111)). For many such 'old-style' tacksmen, the association with place was deeper than that of the lock-keeper, even the gamekeeper, the shepherd and the farmer, because the connection between his family, not just himself, and that land was embedded in time. See Figure 4.

Tacksmen however, just like tenants, were not necessarily tied-legally or emotionally-to a specific place, and the definition of tacksman, and thereby his relationship with his tack, had altered over the eighteenth century. Some were absentee tacksmen, and others could and did move about. Regardless, they might use the name of their tack as a 'title' denoting their status. Recently Donald Meek, in his detailed study of Caolas in Tiree, has demonstrated that not only were there different types of tacksmen but that the definition changed over time. In Tiree this development was largely due to the restructuring and commercialisation of the Argyll estates after 1737. Throughout the late eighteenth century the fourteen joint tenants of Caolas, for example, held a tack under a nineteen-year lease of exactly the same type as the single tacksman in the neighbouring farm of Àird Deas, until 1804 when they became crofters (Meek 2019). This evidence correlates with Eric Cregeen's observation that tenants in Kintyre were classed as 'tacksmen' (Cregeen 1963, p. 127; Cregeen 1969). Meek feels that it is unlikely that these tenants used the term to describe themselves, although in a legal sense that is what they were. Taylor has noted that although in Badenoch old tacksman families held on 
much longer, a similar shift was under way there by the early nineteenth century (Taylor forthcoming, Chapter 2). Despite regional variations, it is clear that the status of 'tacksmen' had fallen considerably over a century and, as commercial relationships developed, technically it merely described a particular type of landholding contract rather than a social role. What then did it mean to the nineteenth-century men whose gravestones attached their names to a particular 'tack'?

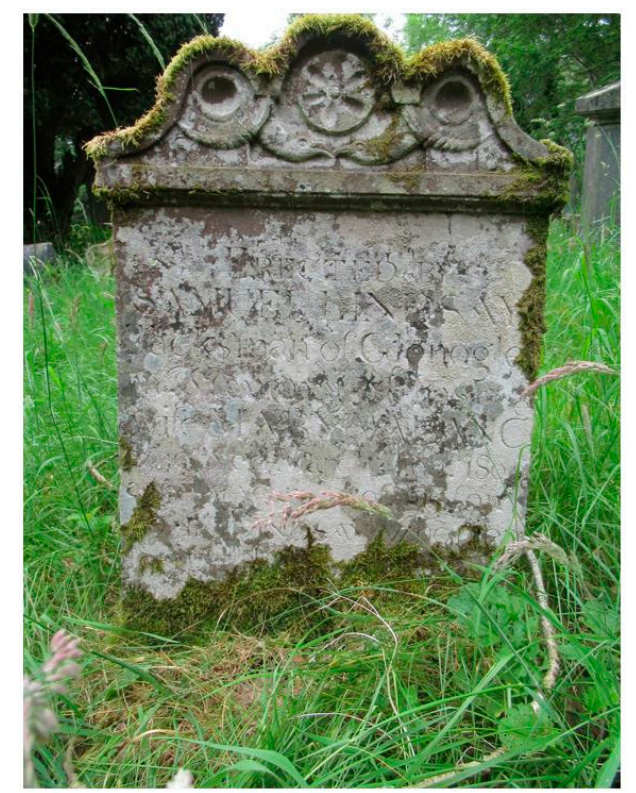

Figure 4. A stone erected by Samuel Lindsay, tacksman of Glenogle, Perthshire in 1800. It is small but ornately carved.

Other than groups of tenants who were legally tacksmen but probably did not use that term to describe themselves, the use of the word 'tack' on nineteenth-century headstones can be ascribed to two sets of men. Malcolm Bangor-Jones has found that some traditional tacksmen families retained the term and that some newcomers, desiring status, adopted it (Bangor-Jones 2019, pers corresp). ${ }^{9}$ An example of the first stands out visually among the gravestones around Laggan church. As was common among people of status in Britain, the MacPhersons, who held the tack of Presmuchrach, used the memorial to Donald (1763-1826) to emphasise their wealth and influence (Buckham 2003, p. 161). They commissioned an elaborate headstone, complete with a fashionable carved Grecian urn and drapery, surrounded by low metal railings. These visual declarations of social rank were paired with descriptions suggesting the fine character of the man, as well as clearly indicating the family's ability to afford a long inscription. Such a man drew his identity as much from his social status, his membership of a local family and his long-standing authority over the residents of the tack as from his association with that piece of land. In the second category, like Bangor-Jones, Taylor has found that in Badenoch, 'the post-Napoleonic years saw the emergence of a new class of lesser tacksmen'- 'middling farmers holding modest sized farms at modest rents' (Taylor forthcoming, Chapter 2). Although the new breed did not fulfil the gamut of roles traditionally expected of a tacksman in clan society, they so designated themselves on their headstones. Taylor notes William MacBean of Dunachtonmore (rent: $£ 18$ ), William Robertson of Dunachtonbeg (£15), and John Robertson of Mains of Dunachton (£26), and speculates that 'they consciously adopted the term for its cultural association of status within Gaelic society' (Taylor forthcoming, Chapter 2). This was not a peculiarly Badenoch phenomenon. Archibald

9 David Taylor found that the Mackintoshes of Balnespick in Badenoch left there in 1747 and moved across the Spey to Dunachton. They were still known as Balnespick into the 1830s but never referred to as of Dunachton. Correspondence November 2019. 
MacLean (1818-1885) was described on his gravestone as tacksman of Greenhill, Tiree. He would have been a single tacksman (without tenants) leasing the farm, and of no particular social status (Meek 2019, pers corresp). So, by the nineteenth century, the headstone description of 'tacksman' could either be to make a point about long-established family connections with dùthchas and social status, or it could be a cultural appropriation far more concerned with social status than place.

Tenants also could be concerned with both status and place. While there is certainly evidence of some mobility of the tenant (and subtenant) strata, many of these men probably had extremely lengthy and secure relationships with a particular place. Their stones consistently record that they were not just tenants-possibly an indicator of social status—but a tenant of a specific place. John Munro (1779-1820) was tenant at Blairich, Rogart; John Stewart (1772-1846) was tenant of Clunemore, Blair Atholl; William Hall (d. after 1858) was tenant at Lagnaha, Kinlochlaich. A cottar or labourer on the other hand had no land and lived by uncertain daily wages or through the tolerance of the tenants. To be a tenant was to be respectable, a man of some means and responsibility. This status is further evidenced by other information on some stones. John Stewart (1760-1838), tenant at Tirarthur, Killin, was also a groundofficer; John Ross (1815-1881) was also a pensioner of the $78^{\text {th }}$ Highlanders. Several men were also church elders: John Sutherland (1721-1815) tenant at Claggin, Rogart; John MacKay (1774-1848) tenant at Colbackie, Tongue; William Ross (1754-1847) tenant at Kilmachalmag, Kincardine. North American historiography has tended to assume that Europeans desired land ownership, although Catharine Wilson has explained that was not always the case (Wilson 2009, pp. 168-89). Within a system where that was not possible, however, tenancy was to be aspired to and, certainly when recorded on stone, identified a long-term relationship of a man with a place. By the mid-nineteenth century, it is likely that men who defined themselves as tenants were renting a more substantial piece of land than a croft or a share of a runrig farm, often one of the new large farms. Those who identified themselves as tenants of a place, therefore, were demonstrating their social status and that they had lived on and worked a piece of land for long enough that they had become associated with it. See Figure 5.

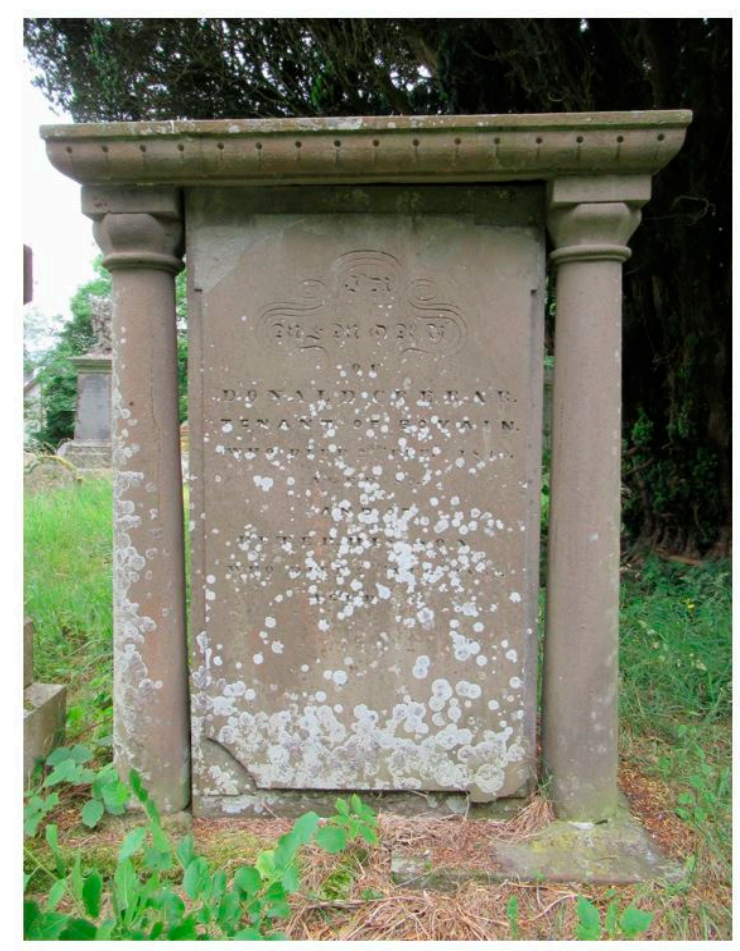

Figure 5. This expensive-looking headstone is for Donald Crerar, the tenant of Bovain, near Killin in Perthshire. 
There are remarkably few headstones which record men as crofters. John Cameron (1817-1880) crofted at Achintore near Fort William, while the fact that Simon Campbell (1820-1888) had a significant headstone was more because of his status among the local religious population than because that he crofted Torgormack, near Beauly. I have found only a few more men designated as crofters across the region. Crofting as a system spread from the late eighteenth century when families were cleared out of the fertile inland straths which they farmed as joint tenants and were coerced into working as farm labourers, fishermen or gathering kelp on the coast. Most were provided with a croft: land under 'three arable acres, sufficient for the maintenance of an industrious family, but pinched enough to cause them turn their attention to the fishing' (Patrick Sellar to Lord Advocate Colquhoun, 24 May 1815 cited in (Adam 1972, p. 156)). In addition, they had access to some communal grazing. Crofts did exist before these clearances, but they were specifically for those who primarily drew their income from a trade or a pension and therefore needed only such a small piece of land (usually 3-6 acres) on which to grow some crops and keep a milk cow (Taylor 2016, pp. 32-34). By the mid-nineteenth century, a large proportion of the population of the rural Highlands and Islands were crofters, although this circumstance is not at all apparent from a reading of headstones. The geographical dislocation, sense of injustice and loss of socio-economic status for the generation of men who went from being fairly autonomous tenant farmers to labourers was psychologically, as well as economically, painful. There is a hint of this process in one inscription. John Sutherland (1788-1861) was known as one of na daoine, or the Men, a local religious leader, and this is primarily what his monument commemorates (MacInnes 1944, pp. 16-41; Paton 2001, pp. 97-144). He was most closely associated with Badbea, a windswept township atop terrifyingly high cliffs in Caithness. Families were settled there after being removed from further inland. They allegedly had to tether their children to prevent them from falling into the North Sea. John was sixteen in 1804 when his family was moved and the gravestone of this crofter makes sure to note his actual place of origin: not Badbea, but Ousdale. It is likely that many crofting families simply did not have the finances to erect a headstone, or continued the custom of marking a grave with a rough-hewn stone, as is evident in the graveyards at Bragar and Little Bernera on the Isle of Lewis, hence their invisibility. ${ }^{10}$ It is also possible that the many stones connecting a man and a place, without noting occupation, are those of crofters. While crofters clearly have a strong connection with place, this is not evident in nineteenth-century headstones, whether because of finances or because they had not adopted 'crofter' as a key marker of identity at that point. See Figure 6 .

For other men, close association with a particular territory came through their professional life. Gamekeepers, factors, groundofficers and shepherds usually took up employment on that estate or farm in adulthood. James Oliver (1794-1854) 'lived as a shepherd on the estate of Langwell [Caithness] for 39 years during which time he deservedly gained the esteem and regard of everyone who knew him.' John Smith (1829-1910) was 'for 56 years factor on the Seafield Estates' in Speyside. Robert Sutherland (1791-1841) was grieve at Dunrobin Farm, near Golspie, Sutherland, and John McDonald (1805-1885) had been keeper at Dulnan, Kinrara, in Badenoch. It was through length of years and the intimate use and organising of the landscape that they came to be identified with it, shaping their self-identity and their identity within the community. See Figure 7.

10 At Bragar, the lines of small stones are interspersed with inscribed headstones marking deaths in the early twentieth century. Some are First World War graves. This suggests that the lines of small, uninscribed stones were still being used as grave markers during that period. 


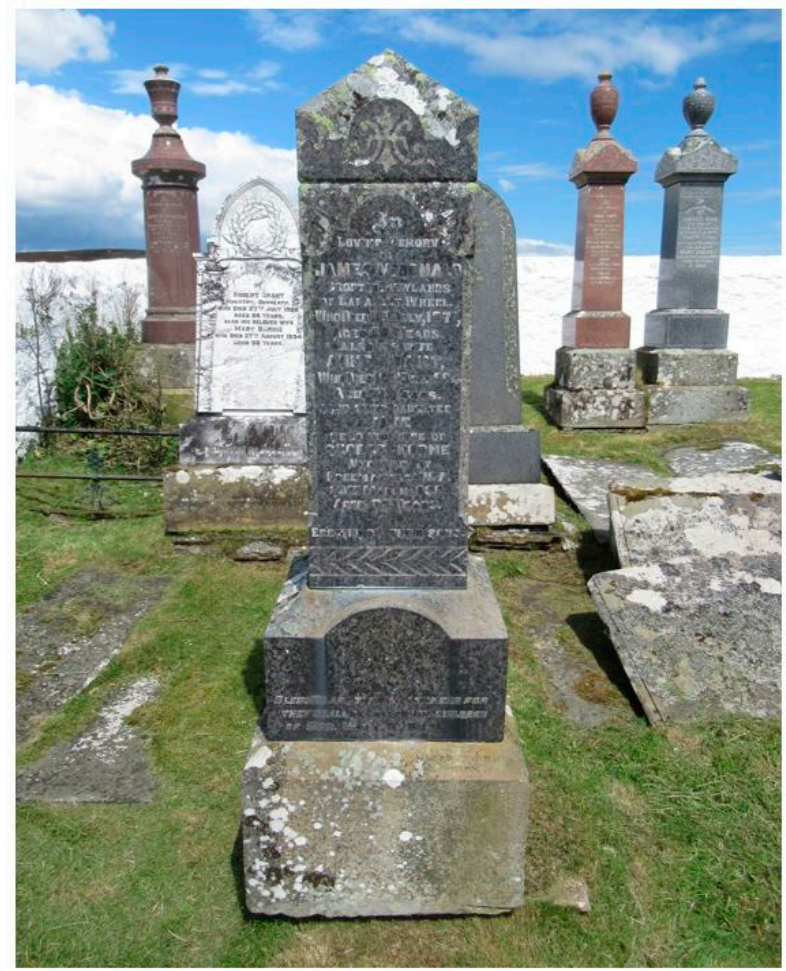

Figure 6. James MacDonald, crofter at Newlands in Caithness, had a fine granite memorial erected to him by his, presumably fairly well-off, sons.

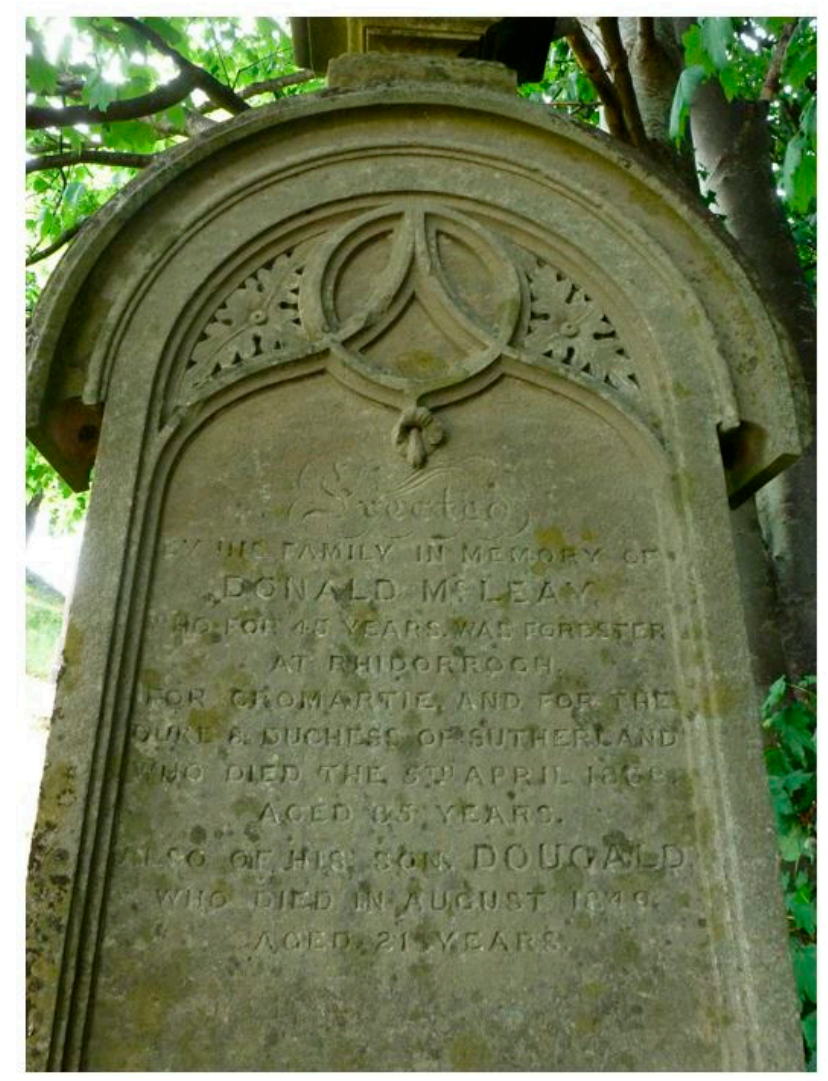

Figure 7. 'Donald McLeay was for 40 years forester at Rhidorrach'. This inscription also ties him to the landowners for whom he worked: 'Cromartie and for the Duke \& Duchess of Sutherland'. 
The other type of men closely associated with a place was clergy. Ministers were responsible for a geographically circumscribed piece of land: a parish. Most did not work the land but were to serve the people of that region. A diligent minister knew his parish by knowing the people and by travelling through it. Many Highland parishes were extensive and most therefore had multiple locations where services were held. Every second Sunday, for example, the Bracadale minister preached in Eynort, fourteen miles from the church (Nicolson 1930, p. 325). A good minister, therefore, visited all corners of his parish regularly to take services and to visit parishioners. Moderate ministers were much castigated by Evangelicals for their laziness and inattention to their duties, so not all ministers necessarily knew their parishes intimately. ${ }^{11}$ However, the much-maligned Moderates were often very interested in farming, so knew the place by cultivating the land and being part of the agricultural community in a way which Evangelicals, more purely interested in their parishioners' spiritual state, did not. Ministers' gravestones note an above-average amount of personal detail. Some rehearsed a man's lengthy association with one parish: David Sutherland (1800-1880) ministered in Farr, on the north coast for thirty-eight years. The subtext of such inscriptions was that the man fully identified with that parish and that the community had, at least in the minds of those who commissioned the stone, adopted him as one of their own. Occasionally, the association of a minister with a place performed the same function as that of the tacksman. Clergy tended to come from gentry or tacksman families. Along with the law or the military, the church was a respectable profession for younger sons. Some ministers were therefore part of a generational association with ancestral territory. There were, for example, three generations of MacKinnon incumbents between 1779 and 1888 in Strath, Skye, traditional MacKinnon lands (Nicolson 1930, p. 375). Similarly the Frasers had a long and deep connection with Kirkhill (Scott 1928, p. 183). Alexander (1748-1802) and Donald (1783-1836), father and son, were consecutively ministers for twenty-nine and thirty-one years within the Fraser clan heartlands. For ministers who moved around, and some were very mobile, their stones almost always record the parish with which they were most closely associated. Some trace a man's professional career through his parishes. See Figure 8. Murdo MacQueen (1848-1912) was Free Church minister at Tarbert on Loch Fyne, then at Kiltearn, Easter Ross. The stone also notes his professional success, rising to the position of Moderator of the General Assembly.

The use of placenames to display Highland male identity is deeply complex, considering the social, economic and cultural flux of the nineteenth century. Reorganisation of social relationships and the relationship between people and places happened over the century, with different estates undertaking change more or less rapidly or at different times. Gravestone evidence from the same time period can therefore speak to very different sets of relationships and feelings of belonging or dislocation. A man's sense of identity as a tenant or tacksman could, for example, pertain to either his position in a community operating under the old system, or to his success in weathering the storm of estate reorganisation or establishing himself within the new regime. 'Farmer' clearly also speaks of status as well as place. By later in the century, a few men describe themselves as 'crofter' on their gravestones. The relative dearth of crofter gravestones is probably largely a function of the expense of purchasing and engraving them, but it probably also speaks of a social identity which took time to build, perhaps only in the generation after tenants were pushed into becoming crofters. While these inscriptions evidently proclaim a social identity, that they are continually linked with place is highly significant.

11 For a discussion of the maligning of Moderate ministers and evidence of their interest in farming, see (MacLeod 1980-1982, pp. 243-69). 


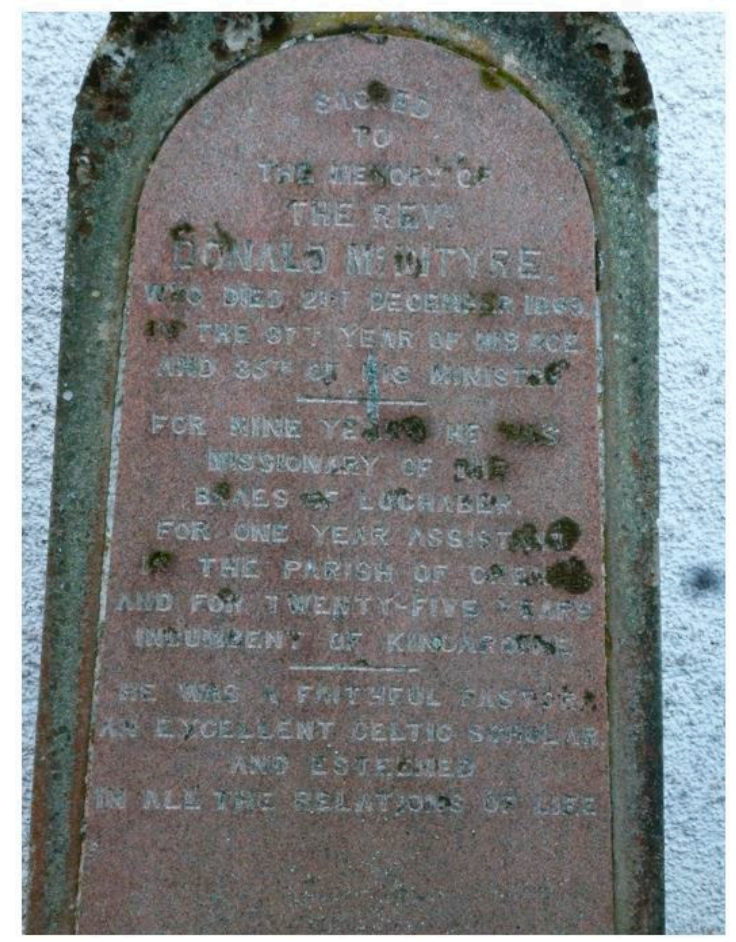

Figure 8. Donald McIntyre served in Braes of Lochaber then two Sutherland parishes, Creich and Kincardine, through a long career in the Church of Scotland. Ministers frequently have their personal attributes enumerated on their stones. McIntyre was honoured for his abilities as a pastor and a Celtic scholar.

\section{Discussion of Findings III: Telling Life Stories: Regional, National and Imperial Identities}

Some men drew an identity from a place larger than their immediate locale. Many nineteenthcentury men were geographically mobile (though usually not transient) and identified with a range of places: a region; the whole of Gaeldom; or parts of the British Empire. Some could uncomplicatedly name where they were from, but the gravestones of others trace the various places that shaped who these men were.

Some stones used places to structure the record of these men's lives: their childhood, work, choices, character. These display an alternative sort of identity from the man who belonged deeply to one place. Noting a birthplace indicates a sense of belonging elsewhere than their abode, suggesting a slightly different self-identity than their neighbours. Walter MacKay (1809-1885) might have 'laboured as a Gaelic teacher in various parts of Skye for forty two years' and died at Dunvegan, but his stone notes he was born in Dornoch, far off on the east coast of the mainland. Donald MacDonald (1869-1889) had 'Achvaddy' in Kilmallie after his name but was a 'native of Stratherrick'. Malcolm MacFadyen (1788-1856), 'a native of Colonsay', was 'for thirty years teacher of Corran school' in Ardgour. John Noble (d. 1908) was Free Church minister in Lairg but 'a native of Ferintosh', Easter Ross. The places to which a man had belonged, combined with other gravestone details, could trace a life history. John Johnson (1796-1861) was born in Achananseileach in the parish of Kilmichael, Argyll. He moved north and for many years was beadle and kirk officer of Kilmonivaig before dying at Killchonate, in that parish. Donald MacQueen (1785-1885) was for forty years the Free Church catechist in Bracadale, but previously he was 'many years a teacher in Skye and Soay'. William Brown (1816-1853), a native of Kirkmichael, Dumfriesshire, was working as a shepherd at Boluthach in Lochaber when he died 'in the faithful discharge of his duties' during the 'great snow storm' of 11 February 1853. See Figure 8.

Occasionally, a gravestone deliberately broadened a man's identification with place beyond specific locations to a county or region. Lewis Russel (1796-1878) was born in Cromdale and died in Conon, Easter Ross. 'He was connected with the county of Ross for half a century as road surveyor 
and inspector of Highland roads and bridges.' Alexander Dewar (1785-1849) was the Congregational minister of Avoch on the Black Isle, but his 'extensive and unwearied labours' were not only for his own flock but for 'his countrymen throughout the Highlands'. John Fraser (d. 1884) was Free Church minister in Rosskeen, Easter Ross. He not only provided 'faithful pulpit services' and 'unwearied pastoral labours' for thirty-one years acquiring the 'warm affection of his large flock', but had a strong influence far further afield: 'his numerous services to the cause of Christ in the Highlands and Islands were always cheerfully rendered and much valued by the Gaelic people whom he loved so well.' Such 'Highlandism' suggests an identity based on place, ancestry and language, but also on what a person did in and for the region or community. This conclusion is not dissimilar to the findings of Frank Bechhofer and David McCrone in their contemporary sociological study of Gaelic identity (Bechhofer and McCrone 2014, p. 128).

Some men's careers enabled them to develop a national, international or imperial identity. John MacLeod (1847-1896) was buried in Avoch, Easter Ross, but his headstone records that for thirty years he had been inspector of the CW (presumably the Combined Workhouse) by Bristol. John Francis Sutherland (1854-1911) died in Tain, Easter Ross, but was born in Lybster, Caithness. In between living in these two northern locations he had worked with HMS Prison Service and had risen to the position of Senior Deputy Commissioner of Lunacy in Scotland. These were men whose sense of identity was both local and national in scope. John MacMillan was born at Tigh-an-Toim, Lochaber in 1840. He made a success of himself in Glasgow as a wine merchant. He died at thirty-eight, leaving enough money for a headstone to be erected to him back in Kilmallie parish. He was described as 'A man of world-wide sympathy and a warm supporter of all the interests of his native country.' The stone does not explain how his 'world-wide' sympathies manifested themselves. He was perhaps interested in the territories of the British Empire, or in charitable activities or missionary societies overseas, of which there were many in his lifetime. His stated affiliation with 'his native country' is also difficult to interpret. He could mean Britain, Scotland, the Highlands or, indeed, Lochaber. 'Country' was often used to refer to what today we could consider a region. ${ }^{12}$

There are a number of gravestones which associate men with parts of the British Empire, or areas of British influence. Frequently the purpose of highlighting such connections was to demonstrate their personal importance and their professional success. Reference to these places confers prestige, worldliness, and perhaps patriotism or exoticism. Particularly for men who had spent many years in these locations, it also suggests an ex-pat identity, where a man might now identify more easily with others who had also lived elsewhere than with those who had never left the country. Sometime after 1884, John Shaw Brown erected a substantial family memorial in Bracadale and ensured the inscription mentioned his career as municipal engineer in Akyab, Burma. Andrew MacKay erected a nicely worked sandstone memorial to his father, John (1785-1859), tenant at the farm of Proncy, Dornoch, and his mother, Marion (1798-1872). At the top of the stone his name, profession as carpenter, and the place he identified with-West Zora, Canada—clearly honour not only his parents but demonstrate his success as an emigrant. In Portree, Donald Murchison's (d. 1910) stone noted his position with the National Bank of India. Other inscriptions invite recognition and respect of another type. Twenty-nine-year-old John Gunn from Dunbeath Mills does not lie beneath his headstone. In 1880 he succumbed, doubtless to disease, at Livingstonia by Lake Nyassa, in today's Malawi, where he was a missionary. His stone utilises the verse from Matthew 25:23, 'well done good and faithful servant'. The respect desired for him was not for any professional status or success but for his Christian character. The Evangelical community would appreciate the philosophy of laying one's life down for the salvation of others. In an era of high imperialism it might evoke for others the civilising mission of the British Empire,

12 For example, in 1811 the minister of Fearn, Easter Ross, referred to 'the Gaelic of the country'; in 1813 Moidart was described as 'a country wholly inhabited by Catholics'; in 1819 Major MacDonald was 'the factor of the country', i.e., the island of Barra. (Edinburgh Society for the Support of Gaelic Schools 1811, 1813, 1819), $1^{\text {st }}$ Annual Report p. 40; $3^{\text {rd }}$ Annual Report p. 30; $9^{\text {th }}$ Annual Report p. 17. 
although missionaries also had a long history of resisting colonial exploitation (Porter 2004, pp. 323-24). Other inscriptions include details of a person who had emigrated. Catherine (1862-1898), who died in Zora, Canada, was included on the headstone of her parents, Donald Sutherland (1815-1888), Ardshave, and Elspth (sic) MacKay (1824-1900). The stone symbolically reunited members of a family separated geographically. It also indicated how family identities, even of those remaining in Scotland, could be transatlantic or international. See Figure 9.

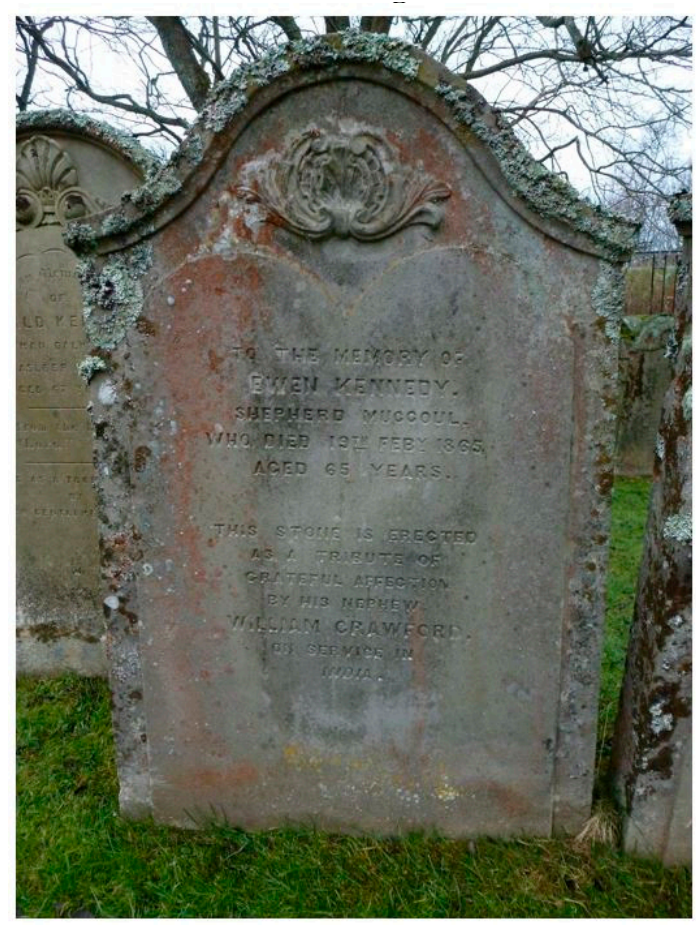

Figure 9. This stone to a shepherd in Laggan parish was paid for by his nephew, William Crawford, who publicises that he is 'on service in India'.

The mass recruitment for the Napoleonic Wars (1792-1815) and then for continued imperial expansion meant many nineteenth-century Highland men were veterans. Many had served for the full twenty years, enlisting as young impressionable men, so the military shaped their personal and public identities. Some noted their service in the same way as any other occupation: Campbell France (1797-1845) was a Royal Navy surgeon; Philip Cameron (1782-1857) from Cluny Mains was in the $79^{\text {th }}$ Foot; and Walter Ross, Ardcronie, (1798-1875) was a pensioner of the same regiment. By the very fact that headstones were erected to them, these three were part of Scotland's 'large and stable population of pensioners', defying the contemporary stereotype of veterans as 'restless, improvident and dissolute' (Cookson 2009, pp. 320, 331). J.E. Cookson's study of post-army lives focuses on the rank and file, most of whom did not have headstones. Nevertheless, his observations provide useful insights into the role the military played in shaping these Highlanders' sense of self. He argues that men, like Walter Ross, used the army as a means to access the relative economic security of a pension; social respect-this is also clear from the inclusion of their service on their gravestones; and settled residence (Cookson 2009, pp. 332-33, 335-37). Pensioners were slightly more mobile than average Scotsmen but those commemorated on gravestones, judging from their local names and biographical details, returned to their region of origin. Military wages and pensions allowed ordinary men to achieve respectability by amassing the funds required to marry and set up a household in their home communities. Men's continued association and sense of belonging to a regiment decades after retirement demonstrate a powerful sense of personal and corporate masculine identity. Cookson notes that pensioners retained 'strong bonds of comradeship', and that, locally, 'old soldiers all knew each other' (Cookson 2009, p. 331). In Reay, Caithness, a local historian recorded 
that veterans of the $93^{\text {rd }}$ wore their regimental tartan to church each Sunday (Cavendish 1928, p. 49) cited in (Cookson 2009, p. 331). For some, military service was less important than the character of the man himself. Although Angus Leslie (1783-1850) was Lieutenant in the $3^{\text {rd }}$ Sutherland Highlanders, his lengthy inscription focuses on claims of his charity, friendship and Christian faith. These are not the standard attributes of military masculinity, such as courage, loyalty, fortitude or sacrifice (Carr 2008, pp. 102, 108). For others, military service was at the core of their being. Donald Campbell from Dornoch (d. 1844) basked in the reflected glory of his time in the 'distinguished regiment' of the $79^{\text {th }}$ or Cameron Highlanders. The inscription commemorating John Ross (1815-1881) displayed his patriotism, social status, professional achievements and character, noting he was a 'Pensioner and tenant [at] Syall who served his Queen and country in the $78^{\text {th }}$ Highlanders for over 21 years, retired in 1860 with medals for Persia, Lucknow, long service and good conduct'. When Lieutenant Colonel D.C. McNaughton erected a gravestone in Inverlochy to various family members, he ensured it recorded his own service in the $13^{\text {th }}$ Prince Albert's Light Infantry. Major W. Grant defined all the male members of his family through their military service when he erected a monument in Inverallan, Strathspey. His father Robert (1785-1852) had served with the $27^{\text {th }}$ Regiment of Foot; his brother David (1832-1860) of the Royal Artillery died at Secunderabad, India, while young Peter (1835-1854), a Scots Fusilier Guardsman, was killed at Inkerman. Alexander (1820-1874) was part of the Merchant Service and died in Australia. Details of overseas service informed the public that these men, and these families, were not only patriotic and British, but they were men of Empire and had seen a great deal of the world. Similarly, the Ross family defined themselves through a mix of lineage and of military status and activity. Although the monument in Kilmonivaig churchyard ostensibly records the ministry of Thomas Ross, it first harks back to the noble ancestry of himself and his wife, who was niece of Lochiel, a key leader in the 1745 Jacobite Rising. The rest of the stone commemorates the careers of their military sons and a grandson, with no mention of any other family members: Lieutenant Colonel David Ross (1781-1850), a 'distinguished soldier of the Madras Army'; Lieutenant General Hugh Ross (1786-1864); Lieutenant Ewen Ross (1790-1869) of the $92^{\text {nd }}$ Highlanders 'who served with his regiment throughout the Peninsula campaign and at the Battle of Waterloo'; and Major General Robertson Ross $(1828-1883) \cdot{ }^{13}$ For these families, men's military service was defining. The pride that emanates from such stones demonstrates the social respect accorded to the soldier. Their headstones marked their British and imperial identities, as well as family status, personal identities and their association with a place at 'home'.

Other men living in the Highlands were permanently associated with other places around the world. Their colour, ethnicity and place of origin marked them out, regardless of their personal sense of identity or their personal association with place. William Anderson was a 'faithful servant for twenty five years of James Horne of Langwell and Donald Horne of Langwell Berriedale. ${ }^{14}$ While the focus of the Hornes, who erected the monument, was on the length of time he had served them, they also noted that Anderson was 'a native of the West Indies'. As he died in 1850 'at an advanced age', it seems highly likely he was born into slavery. The Highlands had strong connections with the Caribbean slave economy (Alston 2002-2004, pp. 208-36; Kehoe 2016, pp. 37-59). The family who leased Langwell, before it was sold to James Horne in 1814, were Andersons with multi-generation links with the West Indies. It is probable he was a mixed-race son of one of them. ${ }^{15}$ There was a fair smattering of people of

13 It is likely that Robertson was the son of Hugh. They are both styled 'of Glenmoidart', denoting social authority based on landholding.

14 The military and sheep rearing activities of Donald Horne were described in glowing terms in (Tancred 1899, pp. 261-63). His evicting activities were recorded by Gunn (Gunn 1879) and are reproduced on the Badbea Families website http: //www.badbeafamilies.com/gallery-10.htm (accessed on 20 December 2016).

15 The Hornes also benefited from slavery. In 1836 Donald Horne and his sister, Isabella McLeay, were awarded $£ 1981$ os $11 \mathrm{~d}$ compensation as co-trustees for her late husband, Kenneth MacLeay, when slaves on his plantation in British Guiana were freed. (Legacies of British Slave-Ownership n.d.) database https://www.ucl.ac.uk/lbs/claim/view/8644 (accessed on 20 December 2016). 
colour, perhaps especially boys sent home to be educated, in the nineteenth-century Highlands. Their skin tone made them inescapably distinctive. In Dornoch in 1801 were three boys, brothers named Hay, with whom Donald Sage was friendly. He described them first by colour before mentioning personality.

They were natives of the West Indies; the offspring of a negro woman, as their hair, and the tawny colour of their skin, very plainly intimated. Their father was a Scotsman ... Notwithstanding the disadvantages of his negro parentage, Fergus was very handsome (Sage 1975, p. 117).

The employer of 'Kopuri Tom' (d. 1877) did not know his date of birth, or even his real name. ${ }^{16}$ This man was a 'Native of the island of Rotumah in the South Pacific Ocean'. Again, he was described as 'the faithful \& attached servant of GF Wood Esq' and he died at Relugas House in Edinkillie parish. These men were set apart from other servants by race and nationality. Although they were not slaves, with weaker local connections their options for changing their occupation or employer were more limited. ${ }^{17}$ However they thought of themselves, their employers identified them through their excellence as servants but also through their exoticism, marked by two interconnected features: their skin colour and the place where they were born.

Gravestone inscriptions tell stories of the lives lived and the identities shaped in and by the places associated with men. They suggest identities that differ from those of their neighbours, are utilised to trace stages of a life history, or make claims of connections to broad regions. The mobile careers of many, especially professionals, tell of British identities, whether within the United Kingdom or forged within the Empire. Such international identities suggest both belonging, through a sense of Britishness and the men's eventual return home, or alienation, where a statement is being made of a separate geographical identity through temporary residence abroad or resettlement in a colony. For some men, racial or cultural separateness was noted through place: their place of origin utilised to mark out a perception of difference, whether that was an identity felt by the commemorated man or not. Gravestones were also used to reunite families separated geographically, potentially creating a transatlantic or imperial sense of communal identity. Again, these statements of place are frequently associated with proclamations of social status or professional achievement. Brief inscriptions can serve multiple purposes.

\section{Conclusions}

Abrams and Ewan's definition of masculinity as 'a set of practices and roles, expectations and attributes' fits with the generally accepted notion that gender is not a static thing which is possessed, but is continually 'performed'. Thus, it is 'a fluid, permeable and contingent construct'. At first glance, a male identity partly based on place is not 'performed' in this way. However, the recording of place in gravestone inscriptions is an identifier which is chosen, just as one could, instead, choose to portray a man through his family relationships, character attributes or social status. Additionally, the selection of which place or places are noted and omitted is an active performative process which shapes the viewer's perception of who that man is or was. My study of gravestone inscriptions, specifically the use of place as an aspect of male identity, would therefore lead me to agree with the consensus of the historians of Scottish masculinity in Abrams and Ewan's book, while broadening the definition from practices, roles, expectations and attributes to encompass factors such as place.

16 Kopuri is an Indian surname. Rotuma is a Fijian dependency.

17 However, A.S. Cowper notes that Anderson latterly ran the Berriedale Inn. I can find no source for this claim which appears in 'Burial grounds of Caithness and Sutherland' Caithness Field Club Bulletin, 3.5 (Cowper 1983). http://www.caithness.org/ caithnessfieldclub/bulletins/1983/april1983/burialgrounds.htm (accessed on 17 August 2020). It is not supported by the 1841 census where the proprietors are MacLeods. As early as 1790, Bishop Geddes notes 'dining at Henderson's' in Berriedale (Anderson 1955, p. 140). It is possible Geddes misheard the name but he does not comment on Henderson being Black. The early date and the given name suggest the proprietor at that time was not William Anderson. 
The use of birthplaces on headstones may indeed be utilised to form and express Scottish ethnic identity when found in a colonial setting. A continuation of the custom of noting placenames in Canada or Australia should not, however, be over-interpreted. Swyripa's interpretation that for Ukrainian colonists on the Canadian Prairies the practice was 'crystallising' a new community or expressing 'alienation from the present and attachment to a faraway past' is not easily transferred to Scottish immigrants for whom this practice was ubiquitous in Scotland (Swyripa 2003, p. 49). Recording place of origin on a gravestone speaks to a far broader sense of identity than ethnic distinctiveness. The inscriptions for men in the Scottish Highlands and Islands demonstrate that places were used to tell multiple stories about who they, and their families, were.

Place-based identity was especially strong if a man was born, lived and died there but, in association with an occupation, the noting of places variously indicated men's social rank, local embeddedness, public service, or national or imperial identity. It has often been assumed that Gaels were inherently conservative and that therefore their association with place was sentimental. The use of place on men's gravestones, however, speaks of a wide range of personal identities. Some men were profoundly shaped by generational connections to one place and the community around it: this speaks of commitment as much as conservatism and there is no need for it to imply sentimentality. Rather it speaks of a physical, economic and cultural connection to the land upon which one's life and survival depend. Other men were defined through their association with multiple locations. These identifiers were utilised to indicate regional, national, international or imperial identities, or to indicate social rank, public service, patriotism or even character traits. Place can be used to make a man stand out from his neighbours, or to embed him even more deeply after death within the geographical community into which he was born or adopted. The sheer ubiquity of placenames appearing on gravestones indicates that, however they were utilised, place was a critical element of male identity in the nineteenth-century Highlands and Islands.

Funding: Much of the research for this paper was funded by the generosity of an Inverness Field Club Bursary awarded in 2017.

Acknowledgments: My grateful thanks to all the kind friends who tolerated being dragged into graveyards and expected to search for inscriptions, including D.J. MacLeod, Alison Creasey, Grace Ritchie, Kirsten Winch, Ben Thomas, Andrew and Margaret Jones.

Conflicts of Interest: The author declares no conflict of interest.

\section{References}

Abrams, Lynn, and Elizabeth Ewan. 2017. Nine Centuries of Man: Manhood and Masculinities in Scottish History. Edinburgh: Edinburgh University Press.

Abrams, Lynn. 2013. The Taming of Highland Masculinity: Inter-personal Violence and Shifting Codes of Manhood, c.1760-1840. The Scottish Historical Review 92: 100-22. [CrossRef]

Adam, Robert James, ed. 1972. Papers on Sutherland Estate Management, 1802-1816. Edinburgh: Scottish History Society, vol. I.

Alston, David. 2002-2004. 'Very rapid and splendid fortunes'? Highland Scots in Berbice (Guyana) in the Early Nineteenth Century. Transactions of the Gaelic Society of Inverness 63: 208-36.

Anderson, William. 1955. Bishop John Geddes: Journal Ambula Coram Deo, Part Second. The Innes Review 6: 131-43. [CrossRef]

Bechhofer, Frank, and David McCrone. 2014. What Makes a Gael? Identity, Language and Ancestry in the Scottish Gàidhealtachd. Identities 21: 113-33. [CrossRef]

Buckham, Susan. 2003. Commemoration as an Expression of Personal Relationships and Group Identities: A Case Study of York Cemetery. Mortality 8: 160-75. [CrossRef]

Carr, Rosalind. 2008. The Gentleman and the Soldier: Patriotic Masculinities in Eighteenth-Century Scotland. Journal of Scottish Historical Studies 28: 102-21. [CrossRef]

Cavendish, Alfred E. J. 1928. An Reismeid Chataich: The 93rd Sutherland Highlanders, 1799-1927. London: Privately Published. 
Cookson, John E. 2009. Early Nineteenth-Century Scottish Military Pensioners as Homecoming Soldiers. The Historical Journal 52: 319-41. [CrossRef]

Cowper, A. S. 1983. Burial Grounds of Caithness and Sutherland. Caithness Field Club Bulletin. p. 3. Available online: http://www.caithness.org/caithnessfieldclub/bulletins/1983/april1983/burialgrounds.htm (accessed on 17 August 2020).

Cowper, A. S., and I. Ross. 1989. Sutherland Monumental Inscriptions pre 1855. Scotland: Scottish Genealogy Society. Cregeen, Eric, ed. 1963. Inhabitants of the Argyll Estate 1779. In Scottish Record Society. Edinburgh: J. Skinner \& Co.

Cregeen, Eric. 1969. The Tacksmen and their Successors. Scottish Studies 13: 93-144.

Davey, William, and Richard MacKinnon. 2001. Nicknaming Patterns and Traditions among Cape Breton Coal Miners. Acadiensis 30: 71-83.

Dodgshon, Robert A. 1981. Land and Society in Early Scotland. Oxford: Oxford University Press.

Dwelly, Edward. 1971. The Illustrated Gaelic-English Dictionary. Glasgow: Gairm.

Edinburgh Society for the Support of Gaelic Schools. 1811. Annual Reports. Edinburgh: National Library of Scotland.

Edinburgh Society for the Support of Gaelic Schools. 1813. Annual Reports. Edinburgh: National Library of Scotland.

Edinburgh Society for the Support of Gaelic Schools. 1819. Annual Reports. Edinburgh: National Library of Scotland.

Giguere, Joy. 2007. Virtuous Women, Useful Men and Lovely Children: Epitaph Language and the Construction of Gender and Social Status in Cumberland County, Maine, 1720-1820. Markers 24: 1-23.

Gunn, Alexander. 1879. Tales of Braemore. Northern Ensign reproduced on the Badbea Families Website. Available online: http://www.badbeafamilies.com/gallery-10.htm (accessed on 20 December 2016).

Kehoe, S. Karly. 2016. From the Caribbean to the Scottish Highlands: Charitable. Enterprise in the Age of Improvement, c.1750 to c.1820. Rural History 27: 37-59. [CrossRef]

Legacies of British Slave-Ownership. n.d. British Guiana 738 (Peter Hall). Available online: https://www.ucl.ac.uk/ lbs/claim/view/8644 (accessed on 20 December 2016).

Lehr, John C. 1989. The Ukrainian Sacred Landscape. A Metaphor of Survival and Acculturation. Material History Bulletin 29: 3-11.

Love, Dane. 1989. Scottish Kirkyards. London: Robert Hale \& Co.

MacDonald, Shamus Y. 2017. "Dh'fheumadh iad àit a dheanamh" (They would have to make a place): Land and Belonging in Gaelic Nova Scotia. Ph.D. dissertation, Memorial University, St. John's, NL, Canada.

MacInnes, Allan. 1996. Clanship and Commerce and the House of Stuart, 1603-1788. East Linton: Tuckwell.

MacInnes, John. 1944. The Origin and Early Development of 'The Men'. Records of the Scottish Church History Society 8: 16-41.

MacLeod, Roderick. 1980. Ministearan an Arain? A Profile of Nineteenth-Century Hebridean Moderates. Transactions of the Gaelic Society of Inverness 57: 243-69.

Meek, Donald. 2019. 'From Runrig Farms to Crofting Community: The Making of the Crofting Township of Caolas, Tiree', Passages from Tiree, 14 September 2018, revised August 2019. Available online: www.meekwrite. blogspot.com (accessed on 12 November 2019).

Newton, Michael. 2009. Warriors of the Word: The World of the Scottish Highlanders. Edinburgh: Birlinn.

Nicolson, Alexander. 1930. History of Skye. Glasgow: Alex MacLaren \& Sons.

Paton, David M. M. 2001. The Myth and the Reality of the 'Men': Leadership and Spirituality in the Northern Highlands, 1800-1850. Records of the Scottish Church History Society 31: 97-144. [CrossRef]

Porter, Andrew. 2004. Religion versus Empire? British Protestant Missionaries and Overseas Expansion, $1700-1914$. Manchester: Manchester University Press.

Reimers, Eva. 1999. Death and Identity: Graves and Funerals as Cultural Communication. Mortality 4: 147-66. [CrossRef]

Ritchie, Elizabeth. 2010. The Faith of the Crofters: Christianity and Identity in the Highlands, 1793-1843. Ph.D. dissertation, University of Guelph, Guelph, ON, Canada.

Sage, Donald. 1975. Memorabilia Domestica: Or Parish Life in the North of Scotland. Edinburgh: Albyn Press.

Scott, Hew. 1928. Fasti Ecclesiae Scoticanae. Edinburgh: Oliver and Boyd, vol. 7. 
Stanley-Blackwell, Laurie, and Michael Linkletter. 2018. Inscribing Ethnicity: A Preliminary Analysis of Gaelic Headstone Inscriptions in Eastern Nova Scotia and Cape Breton. Genealogy 2: 29. [CrossRef]

Stanley-Blackwell, Laurie, and Michael Linkletter. 2020. Looking for Thistles in Stone Gardens: The Cemeteries of Nova Scotia's Scottish Immigrants. In Death in the Diaspora: Gravestones and Memorial Markers across the British World. Edited by Nicholas Evans and Angela McCarthy. Edinburgh: Edinburgh University Press, pp. 81-107. Swyripa, Frances. 2003. Ancestors, the Land, Ethno-Religious Identity on the Canadian Prairies: Comparing the Mennonite and Ukrainian Legacies. Journal of Mennonite Studies 21: 43-70.

Tancred, George. 1899. Annals of a Border Club. Jedburgh: T.S. Small.

Taylor, David. 2016. The Wild Black Region: Badenoch, 1750-1800. Edinburgh: Birlinn.

Taylor, David. Forthcoming. Edinburgh: Birlinn.

Tiree Gravestones. n.d. Available online: www.tireeegraves.org.uk (accessed on 24 September 2019).

Tuan, Yi-Fu. 1974. Topophilia: A Study of Environmental Perception, Attitudes and Values. New York: Columbia University Press.

Wilkie, Benjamin. 2015. Space, Commemoration, and Iconography: Scottish Monuments and Memorials in Australia. In Scots under the Southern Cross: Scottish Impressions of Colonial Australia. Edited by Fred Cahir, Anne Beggs Sunter and Alison Inglis. Ballarat: Ballarat Heritage Services, pp. 157-66.

Wilkie, Benjamin. 2017. Family Networks and the Australian Pastoral Industry: A Case Study of the Port Phillip District and Victoria in the Late Nineteenth Century. Agricultural History 91: 78-95. [CrossRef]

Wilson, Catharine Anne. 2009. Tenants in Time: Family Strategies, Land and Liberalism in Upper Canada, $1799-1871$. Montreal: McGill-Queen's University Press.

(C) 2020 by the author. Licensee MDPI, Basel, Switzerland. This article is an open access article distributed under the terms and conditions of the Creative Commons Attribution (CC BY) license (http://creativecommons.org/licenses/by/4.0/). 